\title{
HOSPITAL LIABILITY: DRAWING A FINE LINE WITH INFORMED CONSENT IN TODAY'S EVOLVING HEALTH CARE ARENA
}

\author{
Shelley S. Fraser*
}

\section{INTRODUCTION}

The quality of health care and its effects on patient care are priority concerns in today's highly regulated and ever changing health care delivery system. A hospital is a multi-care facility, integrating all aspects of patient care, and operating as a profit making entity. ${ }^{1}$ Hospitals hold themselves out to be health care providers, and patients rely on these entities to provide appropriate care. Many hospitals advertise and market their equipment, services, staff, and physicians. A hospital has a duty to ensure that its physicians abide by proper patient care standards. When a patient does not select his or her physician before entering the hospital, the patient must trust that the hospital has assembled a competent staff that can and will perform the procedure properly. In such circumstances, a hospital has a stronger role in ensuring patient safety and care.

The future of hospital liability may involve accountability for physicians who fail to obtain informed consent from their patients and who work primarily within the walls of the hospital. Informed consent is an important aspect of patient care and is an evolving cause of action in medical malpractice liability. A majority of hospitals already assert some control over the informed consent process, by way of policies and procedures, forms, compliance with standards set by the Joint Commission on Accreditation of Healthcare Organizations (JCAHO), and by hiring physicians to perform procedures that require informed consent. Hospital control over the conduct of its staff or physicians is a consideration for liability. ${ }^{2}$ If courts decide to expand certain theories of liability, hospitals will have to be aware of the potential for legal responsibility.

* J.D. Candidate, 2004, Indiana University School of Law - Indianapolis; B.A., 1999, Indiana University, Indianapolis, Indiana. I would like to thank Professor Lawrence Wilkins and Shannon Shaw for their insight and guidance in writing this note.

1. See David H. Rutchik, The Emerging Trend of Corporate Liability: Courts' Uneven Treatment of Hospital Standards Leaves Hospitals Uncertain and Exposed, 47 VAND. L. REV. 535,538 (1994). "Hospitals not only strive to be a source of pride in the local community, but they also seek to avoid operating at a financial loss. Regardless of whether they are profitseeking enterprises, they are run much like any large corporation and must operate in a fiscally responsible manner." Simmons v. Tuomey Reg'l Med. Ctr., 533 S.E.2d 312, 316 (S.C. 2000).

2. See Frank M. McClellan, Tort Liability of Physicians, Hospitals, and Other Health Care Providers, C286 A.L.I.-A.B.A. 1, 18 (1993). 
The doctrine of informed consent could be expanded to include hospital liability for the actions of nonemployee physicians when such physicians are determined to be agents of the hospital by ostensible authority or by the establishment of a nondelegable duty on behalf of the hospital. Courts may take the position that by making hospitals responsible for a portion of the informed consent process when a procedure is performed by a physician who works mainly within the walls of the hospital, a hospital will provide higher quality patient care and confidence throughout the patient population.

Patients do not generally choose their radiologist, anesthesiologist, pathologist, or emergency room physician. These physicians are hired to perform their duties within the hospital, whether in servant/agent relationships or as independent contractors. This lack of patient autonomy, in selecting a physician, may be recognized by courts as a foundation for imposing a duty on hospitals in order to compensate for the decline in patient control. Patient autonomy and self-determination are the founding principles of informed consent. As these principles are reduced in strength by patients not being able to select physicians for specialty procedures or emergency care, hospitals may be held more accountable by the legal system.

On August 28, 2002, the Pennsylvania Supreme Court, in a split decision, drew a fine line concerning hospital liability for lack of informed consent. ${ }^{3}$ In a case of first impression, Valles v. Albert Einstein Medical Center, the court held that "as a matter of law, a medical facility lacks the control over the manner in which the physician performs his duty to obtain informed consent so as to render the facility vicariously liable." ${ }^{4}$ The court reasoned that a "medical facility cannot maintain control over this aspect of the physician-patient relationship."

However, Justice Nigro, dissenting in Valles, reasoned that the informed consent procedure can be viewed as within the scope of the physician's employment because the underlying procedure cannot be performed without it. $^{6}$ Informed consent acts as a prerequisite and is not severable from the procedure. ${ }^{7}$ As long as the procedure is within the scope of the physician's employment, the informed consent to conduct the procedure must also be included in that scope. The dissent's view reflects realities in today's health care delivery system.

This note will discuss the background and evolution of hospital liability related to the doctrine of corporate liability and the history of informed consent. It will analyze the Valles decision, explore the theories of nondelegable duty and ostensible agency authority, and examine emergency room physician and hospital liability, the hospital's involvement in the informed

3. Valles v. Albert Einstein Med. Ctr., 805 A.2d 1232 (Pa. 2002).

4. Id. at 1239.

5. Id.

6. Id. at 1241-42.

7. Id. at 1241 . 
consent process, and patients' reliance on hospitals. Public policy, costs, and the effects on patient care will also be reviewed. Finally, the note will discuss the possibility of a hospital being held liable for failure to obtain informed consent under the theories of agency, non-delegable duty, corporate liability, and voluntary assumption of duty.

\section{CORPORATE LIABILITY THEORY SWEEPS HOSPITALS INTO THE REALM OF OBLIGATION}

Liability involving hospitals has evolved over time. In the early 1900 s, hospitals were not liable for any acts of malpractice committed by their physicians or nurses because of their charitable status. ${ }^{8}$ As hospitals became more like businesses, this immunity ceased to exist, ${ }^{9}$ and hospitals became liable for the negligent acts of their employees. ${ }^{10}$ However, because physicians were independent contractors, liability still did not attach to hospitals for the physicians' negligent acts. With the passage of time, hospital liability has expanded and hospitals have become more accountable to their patients under the doctrine of corporate liability. ${ }^{11}$

The doctrine of corporate liability was first recognized in the landmark case of Darling v. Charleston Community Memorial Hospital, in which the court held that a duty of care was owed to the patient by the hospital independent from the duty owed by a private physician. ${ }^{12}$ The court reasoned that the idea a hospital does not treat the patients or does not act through its physicians and staff is no longer accurate. ${ }^{13}$ "Under the doctrine of hospital corporate liability, a hospital has a nondelegable, direct duty to provide adequate care to all of its patients." 14 The duty does not derive from the respondeat superior theory or the principal-agent theory "because the hospital's liability flows directly from the hospital to its patients." 15

Because the hospital owes a direct duty to the patient, the injured patient does not have to establish negligence on the part of a third party. Hospital

8. Schloendorff v. Soc'y of N.Y. Hosp., 105 N.E. 92, $93-94$ (N.Y. 1914), abrogated by Bing v. Thunig, 143 N.E.2d 3, 9 (N.Y. 1957).

9. See Bing, 143 N.E.2d at 9.

10. See id. The court reasoned that the "hospital's liability must be governed by the same principles of law as apply to all other employers." Id.

11. See Rutchik, supra note 1, at 536. See also Kenneth S. Abraham \& Paul C. Weiler, Enterprise Medical Liability and the Evolution of the American Health Care System, 108 HARV. L. REV. 381, 389 (1994).

12. Darling v. Charleston Cmty. Hosp., 211 N.E.2d 253, 258 (Ill. 1965) In this case, the plaintiff suffered a broken leg playing football. The physician applied a cast too tightly, which cut off the blood flow and thus circulation to the plaintiff's lower leg. An amputation of the lower leg was necessary. The plaintiff brought an action to recover damages for negligent hospital treatment and he prevailed. Id.

13. Id. at 257.

14. Rutchik, supra note 1, at 536.

15. Id. 
duties under corporate liability include showing: (1) duty to furnish adequate equipment and facilities; (2) duty to formulate and follow rules and policies; (3) duty to select physicians properly; and (4) duty to supervise staff physicians properly. ${ }^{16}$

The Pennsylvania Supreme Court adopted the doctrine of corporate liability in Thompson $v$. Nason Hospital. ${ }^{17}$ The court recognized the aforementioned duties and held that a hospital is liable when it "fails to uphold the proper standard of care owed [to] its patient."18 A patient must demonstrate that the "hospital had actual or constructive knowledge of the defect or procedures which created the harm" and that the hospital's negligence was a "substantial factor in bringing about the harm."19

Justice Flaherty, dissenting in Thompson, asserted that hospitals should not be the "guarantors of the quality of care" provided by a physician who is an independent contractor. ${ }^{20} \mathrm{He}$ asserted that this extension of liability would be expanded beyond the hospital and into the corporate business world and that all businesses could be held responsible for the acts of independent contractors. ${ }^{21}$ Justice Flaherty reasoned that this extension of liability would impose detrimental financial burdens on corporations, including hospitals. ${ }^{22}$ Traditionally, informed consent has been the sole responsibility of the physician and hospitals have been exempt from liability in this area. ${ }^{23}$ The main purpose of an action in informed consent is to protect individual autonomy (including the right to choose or decide) and bodily integrity. ${ }^{24}$

16. Id. at $540-48$.

17. Thompson v. Nason Hosp., 591 A.2d 703 (Pa. 1991).

18. Id. at 708 .

19. Id.

20. Id.

21. Id.

22. Id. at 709. See also Mark E. Milsop, Corporate Negligence: Defining the Duty Owed by Hospitals to Their Patients, 30 DUQ. L. REV. 639 (1992). An offspring of corporate liability, enterprise liability was a proposal for malpractice reform in the 1990s. Abraham \& Weiler, supra note 11 , at 381 . Under this approach, malpractice liability would be shifted to the health care organizations where patients are treated and away from individual physicians. $I d$. The idea of enterprise liability is derived from the historic doctrine of respondeat superior. Id. at 383 . The proposal was not accepted by the medical community and was opposed by the physicianowned liability insurance companies because of the serious threat to their market. John F. Bales, III \& Lisa A. DeMarco, Selected Topics in Medical Malpractice Litigation, 669 Practising L. InSt. COM. L. \& PraC. Course HANDBOOK SERIES 381, 418 (1993).

23. See Kelly v. Methodist Hosp., 664 A.2d 148, 151 (Pa. Super. Ct. 1995) ("Every jurisdiction that has considered the issue ... has declined to impose upon hospitals the general duty to obtain informed consent."); See also Suzanne K. Ketler, The Rebirth of Informed Consent: A Cultural Analysis of the Informed Consent Doctrine After Scheiber v. Physicians Insurance Co. of Wisconsin, 95 NW. U. L. REV. 1029, 1037 (2001).

24. See JeSSICA W. BERG ET AL., INFORMED CONSENT 11-12 (2001). See also Bryan J. Warren, Pennsylvania Medical Informed Consent Law: A Call to Protect Patient Autonomy Rights by Abandoning the Battery Approach, 38 DUQ. L. REV. 917, 927 (2000) ("Informed consent has ancient roots ... in the concept of individual bodily integrity free from interference without consent or legal authority."). 
Justice Cardozo set forth the founding precedent with regard to the principle of bodily self-determination in Schloendorffv. Society of New York Hospital, by stating that " $[\mathrm{e}]$ very human being of adult years and sound mind has a right to determine what shall be done with his own body."25 Informed consent became directly related to physicians and the standards they employ when the leading case of Canterbury v. Spence was decided. ${ }^{26}$

Prior to Canterbury, the point of reference was the "physician standard" or the custom of the medical community. ${ }^{27}$ Canterbury injected a new "reasonable patient" standard into the informed consent doctrine. The measurement was an objective one considering the "degree of care which a reasonably prudent person would have exercised under the same or similar circumstances." ${ }^{28}$ The court declared that the standard is set by law and is not one that physicians may or may not choose to impose upon themselves. ${ }^{29}$ The jurisdictions in the United States are evenly split on the two standards, with about half still utilizing the traditional physician-centered standard. ${ }^{30}$ Some commentators have asserted that the reasonable patient standard does a better job of protecting individual autonomy. ${ }^{31}$

Another transformation of the doctrine of informed consent is the theory under which an action is brought. At common law, the action was rooted in the theories of battery or contract (breach of contract or breach of patient/physician fiduciary relationship). ${ }^{32}$ Pennsylvania is the only state that still requires an action in battery. ${ }^{33}$ The majority of jurisdictions base the action on a negligence theory. ${ }^{34}$ The main elements necessary to establish an

25. Schloendorff v. Soc'y of N.Y. Hosp., 105 N.E. 92,93 (N.Y. 1914).

26. Canterbury v. Spence, 464 F.2d 772 (D.C. Cir. 1972).

27. Id. at 783 .

28. Id. at 784 (quoting Wash. Hosp. Ctr. v. Butler, 384 F.2d 331, 335 (D.C. Cir. 1967)).

29. Id. at 784 .

30. Ketler, supra note 23, at 1037. See also BERG ET AL., supra note 24, at 48 . Florida follows the traditional view and "measures a physician's duty by the professional medical standard of what a reasonable physician would disclose under the same or similar circumstances." Roxanne Beth Axelrod, Informed Consent, 36 FLA. JUR. 2D Medical Malpractice $\$ 40$ (2002). For a description of the standard utilized and physician's scope of disclosure for each state see Ketchup v. Howard, 543 S.E.2d 371, 381-86 (Ga. Ct. App. 2000).

31. See, e.g., Ketler, supra note 23, at 1038.

32. Ketler, supra note 23, at 1036; Warren, supra note 24, at 918.

33. See BARRY R. FurRow et Al., Health LAW 312 (2d ed. 2000); Kelly v. Methodist Hosp., 664 A.2d 148, 150 (Pa. Super. Ct. 1995) ("We are compelled to analyze informed consent cases under a battery theory until and unless our Supreme Court decides to recognize an informed consent cause of action grounded in negligence.").

34. See Ketler, supra note 23, at 1036; Warren, supra note 24, at 918 . The breach of contract theory has been held as being against public policy. See Tatham v. Hoke, 469 F. Supp. 914, 918-19 (W.D.N.C. 1979) (holding unenforceable informed consent as a contract); Emory Univ. v. Porubiansky, 282 S.E.2d 903, 905 (Ga. 1981); Grimes v. Kennedy Krieger Inst., Inc., 782 A.2d 807, 858 (Md. 2001) (reasoning informed consent as a contract is only acceptable in non-therapeutic research projects under certain circumstances). See generally Maxwell J. Mehlman, Fiduciary Contracting Limitations on Bargaining Between Patients and Health Care Providers, 51 U. PITT. L. REV. 365 (1990). 
informed consent cause of action include showing (1) "risk was inherent to the medical or surgical procedure undertaken" and (2) the "risk was material, in that it could influence a reasonable person's decision to consent to the procedure." 35 A patient must also prove that a reasonable person would not have consented to the procedure if the material risk had been disclosed and that the lack of informed consent is the proximate cause of the injury. ${ }^{36}$

\section{VALLES V. ALBERT EINSTEIN MEDICAL CENTER}

In Valles v. Albert Einstein Medical Center, ${ }^{37}$ the decedent's sister, administratrix of patient's estate, brought an informed consent action against the physician and a vicarious liability claim against the Albert Einstein Medical Center (AEMC). The decedent's sister, appellant, alleged that the decedent (Valles) was not adequately informed of the risks associated with the contrast dye used in an aortogram (a radiology procedure) and was not advised of alternatives to the procedure. Valles, who was diabetic, presented with a possible abdominal aneurysm. An aortogram was ordered to confirm and identify the location of the aneurysm. ${ }^{38}$ A radiology resident obtained written informed consent from Valles for the procedure to be performed by the radiologist, Dr. Allen. The written consent did not include the risk of renal damage or alternatives to the procedure. Dr. Allen stated that it was his routine practice to inform the patient that the dye from the aortogram might damage the kidneys. Following the procedure, Valles's kidney function worsened and he subsequently went into renal failure. ${ }^{39}$

The appellant asserted that the hospital was liable because it was responsible for the intentional torts of its employee-physicians under the principle of respondeat superior and the hospital had "an obligation to oversee all persons who practice[d] medicine within its walls." 40 Therefore, appellant reasoned that the "hospital as an employer and health care provider in its own right maintain[ed] a right of control in the relationship sufficient to justify the imposition of liability."41 Appellee AEMC contended that the responsibility

35. Elements of Cause of Action, 42A TEX. JUR. 3D Healing Arts \& Institutions $\S 214$ (2002). See also Canterbury v. Spence, 464 F.2d 772 (D.C. Cir. 1972).

36. Elements of Cause of Action, supra note 35. See also Terry O. Tottenham, Informed Consent, 1 HeAlTHL. PRAC. GUIDE $\$$ 9:21 (2002); Lee S. Kreindler et al., Checklist for Medical Malpractice, 15 N.Y. PRAC. SERIES, N.Y. TORTS $\S 13: 46,6$ (2002). Exceptions to the requirement of informed consent include the following: emergency; disclosure would be detrimental to patient's health (cause harm); incompetence; or waiver by the patient. See Canterbury, 464 F.2d at 788-89; BERG ET AL., supra note 24, at 75-125; Ketler, supra note 23, at $1035-36$.

37. Valles v. Albert Einstein Med. Ctr., 805 A.2d 1232 (Pa. 2002).

38. Id. at 1233-34.

39. Id. at 1234.

40. Id. at 1236.

41. Id. 
of informed consent rested solely with the physician performing the procedure and that this duty was non-delegable. ${ }^{42}$

The court addressed the issue of whether a hospital could be vicariously liable for an employee-physician's failure to obtain informed consent as a matter of law. ${ }^{43}$ Finding that the hospital was not liable, the court reasoned that even if it assumed "arguendo" that Dr. Allen was an employee of the hospital, "a battery which results from a lack of informed consent is not the type of action that occurs within the scope of employment." 44 The court noted that it did not want to disrupt the patient-physician relationship with an element of control by the hospital and stated the idea was "improvident and unworkable." 45 Justice Nigro dissented and reasoned that in an action brought under vicarious liability, an employee's conduct is within the scope of employment for purposes of vicarious liability if:

(1) it is of a kind and nature that the employee is employed to perform; (2) it occurs within the authorized time and space limits of the employment; (3) it is actuated at least in part by a purpose to serve the employer; and (4) the use of force is expected by the employer and then force is intentionally used against another. ${ }^{46}$

According to the dissent's view, the aortogram was a radiology procedure that Dr. Allen was employed by AEMC to perform. ${ }^{47}$ The aortogram could not be performed without obtaining informed consent from the patient. If the aortogram was within the radiologist's scope of employment, then the informed consent must also be included in that scope. Accordingly, Justice Nigro asserted that it is well-established in Pennsylvania that informed consent is a prerequisite to any surgery or operative procedure. ${ }^{48}$

The Valles court did not decide whether the radiologist was an employee, agent, or independent contractor. The exact employment status of

42. Id.

43. Valles, 805 A.2d at 1236 . "Vicarious liability refers to those principles which permit the attribution of the acts of one person to another by virtue of the relationship between the two, such as respondeat superior." Timothy A. Hickey, Jr., Vicarious Liability Generally, 14 GA. JUR. Personal Injury \& Torts $\$ 36: 88$ (2002).

44. Valles, 805 A.2d at 1239. As discussed previously, Pennsylvania still adheres to the battery theory for an action in informed consent. See supra note 33 and accompanying text.

45. Valles, 805 A.2d at 1239. The lower court had "determined that nothing in the record indicated that AEMC exercised control over the manner in which Allen was to perform radiology work." Id. at 1235 .

46. Id. at 1241. Justice Nigro believed there was enough evidence that the question of whether Dr. Allen was an employee should have been submitted to the jury. Id. at 1242 .

47. Id.

48. Id. at 1241. Justice Nigro refers to Morgan v. MacPhail, 704 A.2d 617, 619 (Pa. 1997) ("It has long been the law in Pennsylvania that a physician must obtain informed consent from a patient before performing a surgical or operative procedure."). 
a physician to a hospital can make a difference in the outcome of a legal action with respect to hospital liability. When a physician is found to be an independent contractor of the hospital, and not an employee or agent, the hospital is generally not liable for the physician's "professional judgment" unless the hospital was negligent in selecting the physician or asserted control over the physician's activities. ${ }^{49}$

\section{EXCEPTIONS TO THE AGING INDEPENDENT CONTRACTOR DEFENSE}

Labels placed on physicians by contracts or relationships are not dispositive. ${ }^{50}$ Under circumstances "where the hospital retains control over the time, method, and manner of treating patients, the hospital may be held responsible for the physician's actions. Identification of the physician as an independent contractor in the physician's contract with the hospital is not controlling." 51

One of the well-recognized exceptions to non-liability for independent contractors includes the "nondelegable duty" theory. ${ }^{52}$ This theory "provides that an employer such as a health care institution can be held liable for the negligence of an independent contractor performing certain 'nondelegable' duties which are imposed on the employer by statute, contract, charter, or common law." 53 A common example of this exception involves hospital liability in connection with emergency room physicians. ${ }^{54}$

49. Timothy A. Hickey, Jr., Hospital's Responsibility for Physicians, 14 GA.JUR. Personal Injury \& Torts § 36:91 (2002). See also Ward v. Lutheran Hosps. \& Homes Soc'y of Am., Inc., 963 P.2d 1031 (Ala. 1998); Petriello v. Kalman, 576 A.2d 474 (Conn. 1990); Cedars Med. Ctr., Inc. v. Ravelo, 738 So.2d 362 (Fla. Dist. Ct. App. 1999); Churkey v. Rustia, 768 N.E.2d 842 (Ill. App. Ct. 2002); Giese v. Stice, 567 N.W.2d 156 (Neb. 1997).

50. Keller v. Mo. Baptist Hosp. of Sullivan, 800 S.W.2d 35, 37 (Mo. Ct. App. 1990).

51. Hickey, supra note 49. See also Goins v. Tucker, 489 S.E.2d 857, 861 (Ga. Ct. App. 1997), abrogated by 533 S.E.2d 82 (Ga. 2000) (setting forth that "labels ascribed by the contract . . . are not determinative of their legal relationship") (overruled on other grounds); Doctors Hosp. of Augusta, Inc. v. Bonner, 392 S.E.2d 897, 905 (Ga. Ct. App. 1990) ("Such labeling in a contract is not determinative of the status of any such person and other factors may negate the label.").

52. Bales \& DeMarco, supra note 22 , at 466.

The term nondelegable duty is somewhat misleading. A person may delegate a $d u t y$ to an independent contractor, but if the independent contractor breaches that duty by acting negligently or improperly, the delegating person remains liable for that breach. It actually is the liability, not the duty, that is not delegable.

Simmons v. Tuomey Reg'1 Med. Ctr., 533 S.E.2d 312, 317 (S.C. 2000).

53. Bales \& DeMarco, supra note 22, at 466. See also Darling v. Charleston Cmty. Hosp., 211 N.E.2d 253, 257 (Ill. 1965) (reasoning that the "Standards for Hospital Accreditation, the state licensing regulations and the ... bylaws demonstrate that the medical profession and other responsible authorities regard it as both desirable and feasible that a hospital assume certain responsibilities for the care of the patient").

54. Bales \& DeMarco, supra note 22 , at 467,474 . Almost all hospitals provide emergency care and the majority of emergency rooms are staffed by physicians who are independent contractors. 
In Simmons v. Tuomey Regional Medical Center, the South Carolina Supreme Court held that a non-delegable duty was correctly imposed by the appellate court on the hospital for the negligence of an emergency room physician. ${ }^{55}$ The court looked at other industries and relationships that possessed a non-delegable duty and concluded that a hospital owed a nondelegable duty to provide competent emergency care to its patients. ${ }^{56}$ The court noted that the holding was not limited to emergency room physicians, but it was limited to "situations in which a patient seeks services at the hospital as an institution, and is treated by a physician who reasonably appears to be a hospital employee." 57

Similarly, in Jackson v. Power, the Alaska Supreme Court held "that a general acute care hospital's duty to provide physicians for emergency room care is non-delegable." 58 The court also compared the hospital with other industries that have non-delegable duties and reasoned that pubic policy mandates the same protection in an emergency room. ${ }^{59}$ The court stated, "[W]e simply cannot fathom why liability should depend upon the technical employment status of the emergency room physician who treats the patient. It is the hospital's duty to provide the physician, which it may do through any means at its disposal."60

Jackson was later superceded in part by a 1997 Alaska statute declaring immunity to hospitals for negligent acts or omissions of emergency room physicians who are independent contractors and not employees, as long as the hospital provides notice of the physicians' employment status. ${ }^{61}$ Although the case is no longer good law in Alaska, the reasoning presented by the court could be applied in other jurisdictions whose legislatures have not codified

55. Simmons, 533 S.E. $2 \mathrm{~d}$ at 323 (modifying the appellate court's ruling by stating that the duty was not absolute and that the elements of section 429 of the Restatement (Second) of Torts must be satisfied). See infra note 80 and accompanying text. See also Irving v. Doctors Hosp. of Lake Worth, Inc., 415 So.2d 55, 59 (Fla. Dist. Ct. App. 1982); Martell v. St. Charles Hosp., 523 N.Y.S.2d 342, 352 (N.Y. Sup. Ct. 1987).

56. Simmons, 533 S.E.2d at 317-18 (considering the non-delegable duty involved with employer-employee relationship, the landlord-tenant relationship, common carriers, bail bondsman, and municipalities).

57. Id. at 323.

58. Jackson v. Power, 743 P.2d 1376, 1385 (Alaska 1987).

59. Id. at 1383-84.

60. Id. at 1385.

61. AlASKA STAT. $\S 09.65 .096$ (a) (Michie 1997). The statute states:

A hospital is not liable for civil damages as a result of an act or omission by an emergency room physician who is not an employee or actual agent of the hospital if the hospital provides notice that the emergency room physician is an independent contractor and the emergency room physician is insured ....

Id. 
immunity to hospitals in these circumstances. Nonetheless, other courts have declined to extend the non-delegable duty to hospitals. ${ }^{62}$

Corporate liability has evolved to diminish the effects of the independent contractor defense. The court in Urban v. Spohn Hospital held that a hospital could be liable for its own negligence involved in the informed consent process. ${ }^{63}$ The plaintiff informed hospital personnel several times that she did not want a certain procedure and had not consented to it. Nevertheless, the procedure was performed. The treating physician was not informed by the hospital personnel of the patient's wishes. ${ }^{64}$ The court stated, "We cannot say as a matter of law that merely because the physician is ultimately responsible for obtaining consent for medical procedures, that a hospital is therefore totally insulated from liability for all acts relating to such procedures." 65

Similarly, the Supreme Court of Kentucky in Keel v. St. Elizabeth Medical Center noted "incidentally" that the hospital had a duty of informed consent because the Kentucky statute places the duty upon "health care providers." ${ }^{" 66}$ In Keel, the court was referring to the duty of hospital personnel to obtain informed consent prior to performing a CT scan ordered by the patient's physician. ${ }^{67}$

In addition to Urban and Keel, the Pennsylvania Superior Court in Friter v. Iolab Corp. held that the hospital could be liable for failing to obtain informed consent with regard to investigational studies. ${ }^{68}$ The court reasoned that because the hospital assumed an independent duty to obtain informed consent, and because the hospital intended the patient "to come in contact with a foreign substance by way of the investigational study, there is no reason why the hospital should not be held liable under an informed consent cause of action." ${ }^{69}$ The court's holding was narrowly drawn to relate only to informed consent of investigational or research type studies; however, the reasoning may be susceptible to broad application in the future.

Despite the aforementioned cases, courts generally are reluctant to impose any form of liability on a hospital for the failed informed consent of a procedure. Other courts have rejected the Urban court reasoning, and some

62. See Kelly v. St. Luke's Hosp. of Kansas City, 826 S.W.2d 391, 395 (Mo. Ct. App. 1992); Estates of Milliron v. Francke, 793 P.2d 824, 827 (Mont. 1990) (refusing to apply nondelegable duty doctrine to hold hospital liable for the negligent acts of a radiologist, an independent contractor); Baptist Mem'l Hosp. Sys. v. Sampson, 969 S.W.2d 945, 949 (Tex. 1998).

63. Urban v. Spohn Hosp., 869 S.W.2d 450, $452-53$ (Tex. App. 1993).

64. Id. at 452 .

65. Id. at 453 .

66. Keel v. St. Elizabeth Med. Ctr., 842 S.W.2d 860, 862 (Ky. 1992).

67. Id. at 860-61.

68. Friter v. Lolab Corp., 607 A.2d 1111, 1116 (Pa. Super. Ct. 1992). See also Corrigan v. Methodist Hosp., 158 F.R.D. 70, 73 (E.D. Pa. 1994).

69. Friter, 607 A.2d at 1116. 
have held that even though a hospital meets the definition of a health care provider, in many state statutes the hospital does not have a duty to obtain informed consent. ${ }^{70}$ The Supreme Court of Nebraska, in Giese v. Stice, decided that imposing liability on the hospital would not benefit the patient and would result in a disruption of the patient-physician relationship. ${ }^{71}$

The historical mentality has been that hospitals do not practice medicine and therefore should not be held accountable for obtaining informed consent. ${ }^{72}$ Chief Justice Compton of the Alaska Supreme Court agreed, stating, "Hospitals do not practice medicine independently of the individuals they employ." "73 However, he contended that Alaska's statute, which uses the term "health care provider," meant to "impose some responsibility on hospitals to obtain patients' informed consent" and that a hospital should be liable for failing to obtain informed consent when an employee performs a procedure ordered by an independent physician. ${ }^{74}$ Justice Compton noted that the statute imposes a duty for the hospital to make sure patients are informed, either by directing the treating physician or by taking their own initiative. ${ }^{75} \mathrm{He}$ suggested a hospital would be in compliance with this duty by documentation in the patient's medical record or chart. ${ }^{76}$

Even though the Urban, Keel, and Friter courts currently represent the minority view, they may be the beginning of a trend to expand the liability of informed consent outside the physician-patient relationship. The dynamic relationship between a physician and patient has traditionally been one of the leading reasons for not extending liability for informed consent. In 1972, the Rhode Island Supreme Court defined the relationship as a "one-on-one affair." 77 The Valles court was worried about disrupting this "individualized relationship." ${ }^{78}$ However, the court did not attach any significance to the fact that a resident obtained the initial informed consent and the radiologist subsequently added to it. ${ }^{79}$ This dynamic relationship may be slowly deteriorating in today's fast paced, technically advanced delivery of health care.

70. See Giese v. Stice, 567 N.W.2d 156, 164 (Neb. 1997); Ward v. Lutheran Hosps. \& Homes Soc'y of Am., Inc., 963 P.2d 1031, 1038 (Alaska 1998).

71. Giese, 567 N.W.2d at 164.

72. See Pauscher v. Iowa Methodist Med. Ctr., 408 N.W.2d 355, 362 (Iowa 1987). See also Ward, 963 P.2d at 1040; Schloendorff v. Soc'y of N.Y. Hosp., 105 N.E. 92, 93-94 (N.Y. 1914).

73. Ward, 963 P.2d at 1040.

74. Id. at 1040-41.

75. Id. at 1041 .

76. Id. at 1042.

77. Wilkinson v. Vesey, 295 A.2d 676, 688 (R.I. 1972).

78. Valles v. Albert Einstein Med. Ctr., 805 A.2d 1232, 1239 (Pa. 2002).

79. Id. at 1232. "Under the ordinary rules of agency law, the radiologist may delegate the process of obtaining consent to an agent, such as a nurse or even a referring physician, if the agent accepts the responsibility." Stewart R. Reuter, An Overview of Informed Consent for Radiologists, 148 AM. J. ROENTGENOLOGY 219, 224 (1987). The radiologist does this at his own risk. Id. 
Other courts have found hospitals liable for independent contractors under theories of vicarious liability. ${ }^{80}$ Hospitals have been held accountable for negligence involving emergency room physicians utilizing apparent or ostensible agency authority. ${ }^{81}$ The reasoning behind the ostensible agency exception is that hospitals hold themselves out as providing emergency services, and the patients do not know which personnel are employees and which are independent contractors. ${ }^{82}$ The patients rely on the hospital to provide emergency care, not the individual physician. The theory of ostensible agency "applies when a patient comes to a hospital and the hospital selects a doctor to serve the patient. The doctor has apparent authority to bind the hospital because a patient may reasonably assume that a doctor selected by the hospital is an agent of the hospital." ${ }^{83}$

The non-delegable duty and the ostensible agency theories could very easily be applied to all physicians who conduct virtually all of their work within the walls of the hospital. Similar to Jackson, the Pennsylvania Supreme Court in Valles could have inquired as to whether the hospital had

80. Indiana has expressly adopted the theory of ostensible agency set forth in the Restatement (Second) of Torts section 429 for the hospital setting. Sword v. NKC Hosps., Inc., 714 N.E.2d 142, 152 (Ind. 1999). The Indiana Supreme Court held that a hospital could be vicariously liable for the negligent acts of an independent contractor anesthesiologist if an agency relationship was established and if the patient was injured by the anesthesiologist. Id. at $152-53$.

81. Abraham \& Weiler, supra note 11, at 387. The Restatement (Second) of Agency defines an agent or servant as:

One who represents that another is his servant or other agent and thereby causes a third person justifiably to rely upon the care or skill of such apparent agent is subject to liability to the third person for harm caused by the lack of care or skill of the one appearing to be a servant or other agent as if he were such.

RESTATEMENT (SECOND) OF AGENCY: RELIANCE UPON CARE OR SKILL OF APPARENT SERVANT OR OTHER AGENT § 267 (1958). See also the Restatement (Second) of Torts section 429, which describes an employer's liability for independent contractors as follows:

One who employs an independent contractor to perform services for another which are accepted in the reasonable belief that the services are being rendered by the employer or by his servants, is subject to liability for physical harm caused by the negligence of the contractor in supplying such services, to the same extent as though the employer were supplying them himself or by his servants.

RESTATEMENT (SECOND) OF TORTS: NEGLIGENCE IN DOING WORK WHICH IS ACCEPTED IN RELIANCE ON THE EMPLOYER'S DOING THE WORK HIMSELF $§ 429$ (1965).

82. Abraham \& Weiler, supra note 11, at 388.

83. Schlotfeldt v. Charter Hosp. of Las Vegas, 910 P.2d 271, 275 (Nev. 1996). "By furnishing a physician to a patient without a prior relationship with the physician, the hospital is deemed to represent that the physician is its employee and asks the patient to accept the physician based upon its reputation and not that of the physician." Timothy A. Hickey, Jr., Physician as Hospital's Apparent Agent, 14 GA. JUR. Personal Injury \& Torts § 36:92 (2002). Questions for the jury involving ostensible agency include:

(1) [W] hether a patient entrusted herself to the hospital, (2) whether the hospital selected the doctor to serve the patient, (3) whether a patient reasonably believed the doctor was an employee or agent of the hospital, and (4) whether the patient was put on notice that a doctor was an independent contractor.

Schlotfeldt, 910 P.2d at 275. 
provisions in its by-laws to provide radiology services, whether a state statute required acute care hospitals to provide radiology services, and whether the hospital adhered to the JCAHO standards to find a nondelegable duty on behalf of the hospital. ${ }^{84}$

Once a nondelegable duty is established for the radiology services, the duty would have to include the informed consent because of the immutable rule that the services cannot be performed without such consent. Radiologists obtain informed consent from patients daily in the "procedure-oriented nature" of their practice area. ${ }^{85}$ A radiologist is very similar to the emergency room physician because the vast majority of patients do not personally choose or know the radiologist prior to a procedure.

Similar to the nondelegable duty, the ostensible agency theory is directly applicable to radiologists. The theory was upheld against a hospital for the negligence of a radiologist, who was an independent contractor, in Jennison v. Providence St. Vincent Medical Center. ${ }^{86}$ The court reasoned that the "[h]ospital held itself out as providing radiology services to the public" and the patient did not have actual knowledge that the radiologist was a nonemployee, thus satisfying the two elements of ostensible or apparent agency. ${ }^{87}$

Similarly, the Supreme Court of Ohio held a hospital liable under the doctrine of agency by estoppel. ${ }^{88}$ The court stated that a hospital could be held accountable for the "negligence of independent medical practitioners ... if it holds itself out to the public as a provider of medical services and in the absence of notice or knowledge to the contrary, the patient looks to the hospital, as opposed to the individual practitioner, to provide competent medical care." 89

A hospital can attempt to avoid this liability by informing the patient of the exact relationship it has with the physician. ${ }^{90}$ Other suggestions for evading liability include the following:

84. Jackson v. Power, 743 P.2d 1376, 1382-83 (Alaska 1987).

85. Reuter, supra note 79, at 219.

86. Jennison v. Providence St. Vincent Med. Ctr., 25 P.3d 358, 367-68 (Or. Ct. App. 2001).

87. Id. at 367. The two elements are the hospital holds itself out as medical provider and the patient develops reliance because she is unaware of physician's status as an independent contractor. Id.

88. Clark v. Southview Hosp. \& Family Health Ctr., 628 N.E.2d 46 (Ohio 1994). Agency by estoppel involves representation and reliance. "[R]epresentation is satisfied when the hospital holds itself out to the public as a provider of medical services." Id. at 53. Reliance is satisfied by the patient looking to the hospital for medical care, instead of her personal or a specific physician. Id. See also RESTATEMENT (SECOND) OF AGENCY \& 267, supra note 81. Agency by estoppel involves a stricter standard than ostensible agency because actual reliance is required and not just a belief upon representations. Jennison, 25 P.3d at 364 .

89. Clark, 628 N.E.2d at 53.

90. Hickey, supra note 83. See also Sword v. NKC Hosps., Inc. 714 N.E.2d 142, 152 (Ind. 1999) (noting that hospital liability may be avoided by providing the patient with "meaningful notice" of the relationship with an independent contractor physician at the time of admission). 
(1) providing notice of physicians' independent contractor status,

(2) training staff to refer to physicians as independent and private,

(3) posting signs in hospital that state physicians are independent contractors and not employees of the hospital,,$^{91}$

(4) brochures,

(5) avoiding advertising with possessive nouns when referring to physicians,

(6) not permitting physicians to use the hospital name unless acting as an agent,

(7) not providing billing for the physicians,

(8) avoiding financial arrangements with physicians,

(9) not allowing clothing or name tags worn by physician to state the hospital's name, and

(10) disclosing upon the patient's entrance to the emergency room that there are independent doctors available from which the patient can select. ${ }^{92}$

In Churkey v. Rustia, the plaintiff had signed an informed consent form provided by the hospital which stated that she understood the hospital used independently-contracted physicians to perform anesthesia and radiology services. ${ }^{93}$ The form also stated that the "physicians are not employees" of the hospital. ${ }^{94}$ The court held that the physician was not an agent of the hospital and that the plaintiff presented no evidence that the hospital held the physician out as its agent. ${ }^{95}$ The court also stated that if the "patient knew or should have known that the defendant physician was an independent contractor, then the hospital is not liable." 96 By informing the patient of the physician's independent contractor status, the reliance aspect of ostensible authority was

91. See ALASKA STAT. $§ 09.65 .096$ (a) (Michie 1997), which requires notice by the hospitals to avoid civil liability of emergency room physicians who are independent contractors. The notice requirement must meet the following criteria: "(1) be posted conspicuously in all admitting areas of the hospital; (2) consist of a sign at least two feet high and two feet wide, with print at least two inches high; (3) be published at least annually in a newspaper of general circulation in the area;" and (4) describes what language should be included and the physical form it should take. $I d$.

92. Terry O. Tottenham, Suggestions to Avoid Finding of Vicarious Liability/Ostensible Agency, 1 Health L. PRAC. GUIDE § 9:32 (2002). See also Porter v. Sisters of St. Mary, 756 F.2d 669, 670 (8th Cir. 1985) (determining that the hospital was not liable under ostensible agency theory after reviewing a majority of the factors).

93. Churkey v. Rustia, 768 N.E.2d 842, 844 (Ill. App. Ct. 2002).

94. Id.

95. Id. at 847 .

96. Id. at 845 . 
eliminated because the patient had knowledge that the physician was not an employee of the hospital.

To the contrary, the South Carolina Supreme Court, in Simmons, noted that a hospital would "not be allowed to escape liability by giving last-minute notice of independent-contractor practitioners through admission forms or emergency room signs." 97 The court further reasoned that a hospital could be held liable under an agency theory or a nondelegable duty theory for negligent acts of emergency room physicians. ${ }^{98}$

All of the above-mentioned, assertive efforts to promote awareness of the physician's employment status would be better expended if they were used to improve patient care and safety. If patients are faced with a constant barrage of advertising, information, or paperwork to sign concerning how the physicians are not employees of the hospital, patients may suspect that the hospital does not have confidence in the physicians' skills or that the hospital does not support or endorse the physicians working within its facility. On the other hand, one could argue that a hospital promoting the awareness of physicians' employment status would actually be supplying patients with beneficial information that is relevant to their care and well-being.

Nevertheless, many patients are very ill or seriously injured (e.g., emergency room patients) and come to the hospital for care, not a lecture on how the hospital wants to escape being held accountable for the negligent acts of the physicians working primarily within its walls. Accordingly, it has been held that a patient is under no duty to inquire about the employment status of a physician when the patient seeks medical treatment from the hospital. ${ }^{99}$ Patients are often not in a clear, cognitive state of mind when ill or seeking treatment and may not be able to absorb or decipher the information given to them regarding the physician's employment relationship with the hospital. Patients do not need the extra burden of deciding what physician to choose when having a radiologic procedure, undergoing anesthesia, or entering an emergency room.

Actions based on the theory of ostensible agency have been successfully brought against hospitals for negligent acts of radiologists, anesthesiologists, pathologists, and even surgeons when the patient chose the physician because the physician was on the hospital staff. ${ }^{100}$ The ostensible agency theory could be expanded to encompass the informed consent process for any procedure performed by the above-mentioned physicians and emergency room physicians because courts have already included negligent acts under the theory.

In today's health care delivery system, the sacred relationship between a physician and his or her patient is more of an illusion than a reality.

97. Simmons v. Tuomey Reg'l Med. Ctr., 533 S.E.2d 312, 320 (S.C. 2000).

98. Id.

99. Grewe v. Mount Clemens Gen. Hosp., 273 N.W.2d 429, 432-35 (Mich. 1978).

100. Abraham \& Weiler, supra note 11, at 388. See also Terry O. Tottenham, Ostensible Agency, 1 HeAlth L. PRAC. GUIDE § 9:30 (2002). 
"Obtaining informed consent requires time for discussion. As physicians feel increased pressure to see more patients, particularly in the managed care setting, full disclosure and open discussion is less likely to occur." ${ }^{101}$

In the Valles case, the informed consent procedure does not appear to create a relationship between the radiologist and the patient, let alone an individualized connection, as the court contends. The main reason the Pennsylvania Supreme Court refused to extend liability to the hospital was not that the responsibility rested solely on the physician, but that informed consent was not within the scope of employment. ${ }^{102}$ The dissent in Valles provided a very persuasive argument to the contrary. Other jurisdictions may agree with the dissent and conclude that informed consent is an essential part of the radiologist's daily responsibilities; therefore, it is apparent that informed consent is within the scope of his or her employment.

In many cases, the relationship between the patient and physician does not exist prior to the procedure. The procedures involving radiologists are an excellent example of this. "[T] he patient-radiologist relationship tends to be brief and episodic, so that radiologists may not feel comfortable discussing the risks and complications of their procedures with the patient." 103 In addition, the radiologist may not be aware of the alternatives of treatment that are not radiologic in nature; therefore, he or she may not be able to adequately inform the patient. ${ }^{104}$ The radiologist example defeats the argument set forth in Kelly v. Methodist, that "by virtue of his relationship with the patient, the physician is in the best position to know the patient's medical history and to evaluate and explain the risks of a particular operation in light of the particular medical history." 105

The physician who orders a radiologic procedure is required to explain the other alternatives to the patient; ${ }^{106}$ however, the ordering physician may not know all of the risks associated with the radiologic procedure and thus will not be able to adequately inform the patient about the procedure. Despite any obligation on the ordering physician to provide alternatives or information to his or her patient, the legal responsibility of informed consent has traditionally been placed on the radiologist's shoulders. Because the radiologist is primarily responsible for obtaining informed consent, the individualized relationship noted in Valles often does not exist, especially when a patient does not select the physician performing the procedure (e.g., a radiologist, anesthesiologist, or emergency room physician).

101. BARRY R. FURROW ET AL., supra note 33, at 340.

102. Valles v. Albert Einstein Med. Ctr., 805 A.2d 1232, 1239 (Pa. 2002).

103. Reuter, supra note 79, at 219.

104. Id. at 224.

105. Kelly v. Methodist Hosp., 664 A.2d 148, 151 (Pa. Super. Ct. 1995) .

106. "[A] doctor recommending a particular procedure generally has, among other obligations, the duty to disclose to the patient all material risks involved in the procedure." Pauscher v. Iowa Methodist Med. Ctr., 408 N.W.2d 355, 358 (Iowa 1987). 
In addition, physicians are not the only individuals performing procedures which require informed consent. Hospital personnel (e.g., nurses, ER techs, radiologic technologists, and other medical professionals) are also obtaining informed consent. A hospital may be held liable for the negligent acts of its employees under the theory of respondeat superior. ${ }^{107}$ Less inquiry is required into the hospital's role in an employee's negligent act compared to its role in an independent physician's negligent act. In either case, hospitals need to be aware of the potential liability that may result from involvement in the informed consent procedure.

\section{VOLUNTARY ASSUMPTION OF DUTY BY INCREMENTS OF CONTROL}

Hospitals are taking on more responsibility and exerting more control over patient care than they have in the past. Government funded regulations, the structure of health care networks, and the proliferation of medical malpractice litigation have led to less autonomy of the physician and an increase in control of patient care by the hospital. ${ }^{108}$ Along with this increase in control, hospitals' liability has expanded for negligent acts of their physicians. ${ }^{109}$ This new acquisition of control can be depicted as an assumption of duty. Under tort law, "a defendant may voluntarily assume a duty by affirmative conduct which would not exist in the absence of such conduct."

By exerting some control over the informed consent process, hospitals could be characterized as assuming a duty to properly inform patients prior to procedures. One aspect of control, although minimal, is the promulgation of policies and procedures for informed consent. Adopting policies and procedures alone will not generally create hospital accountability.

In Kelly, the Superior Court of Pennsylvania rejected appellant's claim that the hospital's adoption of a policy requiring physicians to obtain informed consent was a voluntary assumption of duty to ensure informed consent occurred. ${ }^{111}$ The court reasoned, "It is highly unlikely the hospital, in adopting its rule requiring that a written consent form be signed, intended to assume a duty greater than that imposed by law." 112 The court also noted, "It was not intended to shift the burden of obtaining informed consent from the physician

107. See Robin Frye Bond, Respondeat Superior, 1 HEALTH L. PRAC. GUIDE $§ 1: 4$ (2002). Liability will be imposed on the "healthcare provider for acts of its employees that are committed while performing within the scope of their employment." Id.

108. See Linda B. Johnston, Playing Doctor: Who Controls the Practice of Medicine?, 66 ST. JOHN's L. REV. 425, 429-30, 441 (1992). Control is witnessed through employeestructured health plans, increased decision making in order to avoid litigation, and compliance with federal and state regulatory schemes. $I d$.

109. Id.

110. Stephanie A. Giggetts, Voluntary Assumption of Duty, 1 SUMMARY PA. JUR. 2D Torts $\S 2: 4$ (2002).

111. Kelly v. Methodist Hosp., 664 A.2d 148, 151 (Pa. Super. Ct. 1995).

112. Id. 
to the hospital nor does it obligate the hospital to guarantee a patient tenders informed consent." 113 However, the decision was based on a battery theory for informed consent, ${ }^{114}$ and one has to contemplate whether the court would have reached the same result if Pennsylvania had adopted a negligence standard for informed consent, as the majority of states have done.

Similarly, the Supreme Judicial Court of Maine refused to recognize the theory of corporate liability in a cause of action against a hospital for failing to enact regulations or policies that controlled the actions of independent physicians. ${ }^{15}$ The court stated, "There exist serious and unanswered public policy questions regarding the wisdom of requiring hospitals to control the medical judgments and actions of independent physicians practicing within their facilities." 116 The court mentioned public policy inquiries of patient safety, quality of care, welfare of the public, and economic considerations. ${ }^{117}$

Even though formulating policies and procedures alone are ordinarily not enough to impose liability, doing so may become a factor in evaluating the amount of control a hospital exerts toward informed consent. "A hospital has a duty to its patients to use reasonable care in formulating the policies, procedures, rules, bylaws, etc., by which its medical staff and nonphysician personnel will be governed."118 "Some courts have recognized a duty to use due care in enforcing such policies and procedures and in ensuring that they are not violated."119 A hospital can be liable for a breach of either of the above duties if it is the proximate cause of the patient's injury. ${ }^{120}$

Hospitals have been held liable for failing to enforce policies, failing to implement proper policies, and for enacting deficient protocols. The Oregon Court of Appeals imposed liability on a hospital for the omission of a policy or protocol governing verification of a central line placement when a patient was transferred from the operating room to the Post Anesthesia Care Unit (PACU). ${ }^{121}$ The hospital had a written nursing policy regarding non-urgent line placement outside the surgical area. The policy contained information stating that only credentialed physicians can insert a central line and that a chest $\mathrm{X}$-ray is required for line verification.

113. Id.

114. Id. at 150 .

115. Gafner v. Down E. Cmty. Hosp., 735 A.2d 969, 979 (Me. 1999).

116. Id. at 980 .

117. Id. at 978,980 .

118. Terry O. Tottenham, Negligence in the Formulation and Enforcement of Policies, Procedures, and Rules, 1 HEALTH L. PRAC. GUIDE § 9:36 (2002).

119. Id. Hospitals can be sued under the corporate negligence theory for failing to "formulate, adopt, and enforce adequate rules and policies to ensure quality care for the patients." Thompson v. Nason Hosp., 591 A.2d 703, 707 (Pa. 1991); accord Corrigan v. Methodist Hosp., 158 F.R.D. 70, 73 (E.D. Pa. 1994).

120. Tottenham, supra note 118.

121. Jennison v. Providence St. Vincent Med. Ctr., 25 P.3d 358, 363 (Or. Ct. App. 2001). 
However, the hospital did not have a written or oral policy regarding the course of action that is to be taken once the $\mathrm{x}$-ray is reviewed by a radiologist. ${ }^{122}$ The clinical imaging manager conceded in her testimony that in relaying the results of a chest $\mathrm{x}$-ray, the radiologist could potentially call up to five different people with the central line placement results and no written documentation was mandated once someone received the telephone call from the radiologist. ${ }^{123}$ Thus, the results may have never reached the inquiring physician and were not documented anywhere. The lack of a policy to control what happened after the central line verification was negligence on behalf of the hospital. ${ }^{124}$

Similarly, the Pennsylvania Superior Court reasoned that hospitals could be held accountable for establishing deficient standards. ${ }^{125}$ The court stated, "If the hospital itself (through its official committee on infection control) adopts a substandard rule for changing intravenous catheter sites, then it may be liable in its corporate capacity." 126

\section{A. Assertion of Control by Compliance with JCAHO Standards}

The majority of hospitals formulate policies and procedures pursuant to JCAHO guidelines. JCAHO is a voluntary independent accrediting body for hospitals; however, accreditation by JCAHO is required for Medicare and Medicaid reimbursement and recognition under most state licensing requirements. ${ }^{127} \mathrm{JCAHO}$ has been considered evidence of the standard of care by many courts in determining whether a hospital has been negligent. ${ }^{128}$ The

122. Id. The policy only mandated the verification of the line placement.

123. Id. The radiologist could have called the results to the patient's nurse, patient's surgeon, a resident assisting the surgeon (if applicable), anesthesiologist, or the floor (PACU). Id. Arguably, an acceptable policy would designate one person or position that would always receive the call and be responsible for documentation of the results in a specified area of the chart.

124. Id.

125. Edwards v. Brandywine Hosp., 652 A.2d 1382, 1388 (Pa. Super. Ct. 1995).

126. Id. at 1388.

127. See Craig W. Dallon, Understanding Judicial Review of Hospitals' Physician Credentialing and Peer Review Decisions, 73 TEMP. L. REV. 597, 603 (2000); BARRY R. FURROW ET AL., THE LAW OF HEALTHCARE ORGANIZATION AND FINANCE 155-59 (4th ed. 2001). "JCAHO was organized in 1952 by the American Medical Association, the American College of Physicians, and the American Hospital Association." Rutchik, supra note 1, at 556. The two main goals of JCAHO are "to improve overall patient care and to establish minimum standards that hospitals must follow to receive accreditation." Id. "The Joint Commission develops all its standards in consultation with health care experts, providers, measurement experts, purchasers, and consumers. Standards are generally updated every two years and change only to improve clarity or reduce duplication." JOINT COMM'N ON ACCREDITATION OF HEALTH CARE ORGS., at http://www.jcaho.org/accredited+organizations/hospitals/standards/standards.htm (last visited Nov. 21, 2003).

128. Bales \& DeMarco, supra note 22, at 493. See also Penn Tanker Co. v. United States, 310 F. Supp. 613, 618 (S.D. Tex. 1970) (finding the hospital liable for negligence in failing to 
failure to comply with such standards is not negligence per se, but may be evidence of negligence on behalf of the hospital. ${ }^{129}$ JCAHO guidelines can also be reviewed along with institutional protocols to determine a hospital's duty to its patients. ${ }^{130}$

JCAHO has established standards for informed consent. The standard set forth is, "Before obtaining informed consent, the risks, benefits, and potential complications associated with procedures are discussed with the patient and family." TX.5.2.1 adds, "Alternative options are considered."131 The intent of these standards is that "[p]atients receive adequate information to participate in care decisions and provide informed consent." 132 JCAHO provides examples of evidence of administering these standards, including interviews with patients, interviews with clinical staff, informed consent policies, and documentation in medical records. ${ }^{133}$ By adhering to the JCAHO standards, the hospital has exerted some control (even though it may be depicted as minor) over the informed consent process. The hospital's compliance with and enforcement of JCAHO standards may be viewed by courts as voluntarily assuming a duty to ensure patients are informed prior to procedures.

\section{B. Another Element of Control-Informed Consent Forms}

Hospitals are interjecting a control element into the informed consent procedure by creating consent forms to be used by physicians and hospital personnel. A recent study concerning informed consent forms was published in the Archives of Surgery. ${ }^{134}$ The study involved an analysis of 540 informed

enforce policy that had been enacted pursuant to JCAHO standards).

129. Bales \& DeMarco, supra note 22, at 496 . Courts have treated the issue of liability pursuant to JCAHO standards inconsistently. In Pedroza v. Bryant, 677 P.2d 166, 171 (Wash. 1984), the Washington Supreme Court stated that the hospital's standard of care is established by JCAHO standards and the institution's bylaws adopted pursuant to those standards. In contrast, the Superior Court of California, in Gonzales v. Nork, 131 Cal. Rptr. 717, 718 (Cal. App. 1976), reasoned that the JCAHO standards were vague and not enough to insulate the hospital from liability (not used as a standard of care). Rutchik, supra note 1, at 562-63.

130. Bales \& DeMarco, supra note 22, at 496.

131. JOINT COMM'N ON ACCREDITATION OFHOSP. \& HEALTHCARE ORGS., COMPREHENSIVE ACCREDITATION MANUAL FOR HOSPITALS 94, TX-37 (2001).

132. Id.

133. Id.

134. Melissa A. Bottrell et al., Hospital Informed Consent for Procedure Forms: Facilitating Quality Patient-Physician Interaction, 135 ARCHIVES SURGERY 26, 26-33 (2000). The study focused on three objectives:

[T]o determine the purpose of and what information is included in informed consent for procedure forms; to examine the extent to which the forms meet accepted medical, ethical, and legal standards; and to explore whether existing forms are capable of enhancing interactions between patients and physicians or other health care providers.

Id. at 27. 
consent forms from 157 hospitals nationwide. ${ }^{135}$ Out of all of the forms, $62.9 \%$ were for specific purposes, $32.9 \%$ were general forms, and $4.2 \%$ were used for a series of procedures or were not classified. ${ }^{136}$

The authors' conclusion was that the majority of the consent forms did not meet accepted standards (i.e., statutes, JCAHO standards, and commonly accepted professional standards) of informed consent or patient-physician interactions. ${ }^{137}$ Ideally, well-designed forms should "foster the use and retention of meaningful information and enhance the quality of patient-physician interactions," 138 thus benefiting patient care. In order to avoid liability, consent forms should contain the following minimum content elements: (1) the nature of the procedure, (2) the risks involved, (3) the benefits of procedure, and (4) the alternatives. ${ }^{139}$

Informed consent forms can be advantageous because they "provide valuable information to which the patient can refer, they provide information about some specific set of risks and benefits, and they provide concrete evidence that some information was transmitted to, and some assent obtained from, the patient." 140 On the other hand, forms are "frequently written in great detail and use medical and legal terminology far beyond the capacity of many patients." 141 Thus, the forms can be a hindrance to the informed consent procedure. Hospitals developing forms need to be mindful of the terminology used and what information needs to be conveyed for a specific procedure. By creating forms, hospitals may greatly benefit patient care, but in the process, they are exerting a control element into the informed consent procedure. Development of forms may add weight to the liability theory of voluntary assumption of duty on behalf of the hospital.

As technology advances, informed consent forms may be replaced by computerized interactive devices, such as CD-ROMs or computer based training modules that explain a procedure, provide possible alternatives and risks, and then attain the patient's understanding of the information provided. ${ }^{142}$ Computerized devices would have to be installed by the hospital and physicians, working solely within the hospital, would use these devices to inform their patients about procedures. In this future scenario, a hospital would be the main source of informed consent-by developing or purchasing these electronic devices and installing them within the hospital network system. Hence, the already atrophying physician-patient relationship would

135. Id. at 26.

136. Id. at 28 .

137. Id. at 26 .

138. Id. at 27.

139. Bottrell et al., supra note 134, at 26.

140. Lois Margaret Nora \& Robert J. Benvenuti, III, Medicolegal Aspects of Informed Consent, 16 NEUROLOGICAL CLINICS N. AM. 207, 211 (1998).

141. Id.

142. See generally Arnold J. Rosoff, Informed Consent in the Electronic Age, 25 AM. J.L. \& MED. 367 (1999). 
be almost nonexistent. This future vision, however, may contribute to better patient protection and better choices by the patient, thus positively affecting the quality of patient care and decreasing the potential for malpractice claims.

Hospitals also have a due diligence duty to avoid causing harm. ${ }^{143} \mathrm{~A}$ hospital can breach this duty "by any legally harmful act or omission which might have been foreseen and avoided, especially when the person injured is one for whose safety and protection the defendant was at the time under some special obligation to act with due foresight."144 By hospitals becoming involved in the informed consent process through JCAHO standards, policies and procedures, promulgation of forms, or future computerized devices, it is foreseeable that a person could be injured by negligent acts of a physician, working primarily within the walls of the hospital, during the informed consent procedure.

\section{ApPearance as a Patient Care Provider Through ADVERTISING AND MARKETING}

Today, hospitals are holding themselves out as patient care providers. The Darling court, in 1965, abandoned charitable immunity and adopted corporate liability for hospitals, noting that hospitals "do far more than furnish facilities for treatment."145 The court reasoned that hospitals employ large staffs, including physicians, nurses, interns, administration, and manual workers, in addition to charging patients for care and taking legal action to collect upon outstanding debts. ${ }^{146}$

The hospital's larger function is even more apparent today. "As an industry, hospitals spend enormous amounts of money advertising in an effort to compete with each other for the health care dollar, thereby inducing the public to rely on them in their time of medical need."147 The public is neither interested in nor cognizant of all the technical complexities involved with contracting and employment relationships between the medical professionals and the hospital. ${ }^{148}$

143. Stephanie A. Giggetts, Duty to Use Due Diligence to Avoid Causing Harm, 1 SUMMARY PA. JUR. 2D Torts § 2:7 (2003).

144. Id.

145. Darling v. Charleston Cmty. Hosp., 211 N.E.2d 253, 257 (IIl. 1965). See also supra note 12 and accompanying text. The Simmons court provided an explanation for the alterations in the hospital's role of patient care: "Among the many forces that have caused this ... change are the commercialization of the practice of medicine, the public's demand for access to modern medical technology, the prevalence and impact of government-funded programs such as Medicare and Medicaid, and the rise of managed care in the private sector." Simmons v. Tuomey Reg'1 Med. Ctr., 533 S.E.2d 312, 317 (S.C. 2000).

146. Darling, 211 N.E.2d at 257.

147. Clark v. Southview Hosp. \& Family Health Ctr., 628 N.E.2d 46, 53 (Ohio 1994).

148. Id. 
Justice Waller, writing for the majority in Simmons, described the modern hospital agenda as follows:

Today, hospitals compete aggressively in providing the latest medical technology and the best facilities, as well as in attracting patients and physicians who will funnel patients to them .... Like any business dependent upon attracting individual people as customers, hospitals in the aggregate spend billions to advertise their facilities and services in a variety of media, from newspapers and billboards to television and the Internet. ${ }^{149}$

Advertising and marketing campaigns have significant effects on a patient's reliance on a health care provider. In Clark v. Southview, the Supreme Court of Ohio concluded that through its advertising and marketing, the hospital held itself out as having the "latest technology and equipment" and as being able to "handle all major medical emergencies." 150 The plaintiff demonstrated reliance through her pre-emergency request to go to the defendant hospital in the event of an emergency, which required her to travel a farther distance than if she had chosen another hospital. ${ }^{151}$

A hospital's marketing and advertising of technology and physicians impacts the way patients make their medical decisions. By using such marketing techniques, hospitals are endorsing the physicians that are associated with the hospital. Patients who look to the hospital in order to select a physician, such as a radiologist, anesthesiologist, emergency room physician, and occasionally a surgeon, trust the hospital's judgment of its physicians. Accordingly, in Bing v. Thunig, the high court of New York reasoned, "Certainly, the person who avails himself of 'hospital facilities' expects that the hospital will attempt to cure him, not that it [sic] nurses or other employees will act on their own responsibility."152

The public's increased reliance on the hospital leads to the greater likelihood of liability. ${ }^{153}$ Reliance may be viewed as a form of dependency. A relationship that is characterized as involving dependency and disparity of power gives way to a fiduciary obligation or responsibility. ${ }^{154}$ These relationships "require heightened standards of good faith, honesty, and trust on the part of the fiduciary." 155 Hospitals may be viewed by the courts as establish-

149. Simmons, 533 S.E.2d at 316-17.

150. Clark, 628 N.E.2d at 46.

151. Id. at $54 \mathrm{n} .1,55$.

152. Bing v. Thunig, 143 N.E.2d 3, 8 (N.Y. 1957).

153. See Pedroza v. Bryant, 677 P.2d 166, 169 (Wash. 1984).

154. Richard A. Heinemann, Pushing the Limits of Informed Consent: Johnson v. Kokemoor and Physician-Specific Disclosure, 1997 WIS. L. REV. 1079, 1090.

155. Id. 
ing fiduciary relationships with patients who come to the hospital for medical treatment and trust that the hospital will cure them.

Public policy plays an important role in the accountability of heath care actors and entities. "Public policy dictates that the public has every right to assume and expect that the hospital is the medical provider it purports to be." 156 The image of the hospital as protecting the public has shifted to a business-like image largely because the hospital is a profit making corporation, which has its own interests in mind. "[T]he basis of hospital liability analysis was once that protecting the hospital benefitted [sic] the public as a whole, the focus is shifting to the expectations of the public and the individual patient, who is to be protected at the hospital's expense."157 Commentators contend that public policy necessitates accountability on the hospital's distributive role as edging closer to a strict liability theory. ${ }^{158}$

Why should informed consent be treated differently than other medical malpractice actions involving a physician and a hospital? Under the doctrine of corporate liability, hospitals have a duty to supervise physicians and promulgate policies and procedures-both are involved in the procedure of informed consent. The sacred physician-patient relationship in Valles is rarely present with the physicians who work primarily within the walls of the hospital, and the main goals of informed consent, patient autonomy, and selfdetermination may actually be better protected if the hospital plays a role in the informed consent procedure. ${ }^{159}$

Imposing the duty of informed consent on a hospital can be viewed as advantageous in several ways. First, the hospital is the logical nexus for ensuring that informed consent is obtained from a patient. Some physicians are unwilling to acquire a patient's informed consent in the hospital setting, and the hospital will now have the incentive to pursue informed consent. ${ }^{160}$ Second, the current trend in other areas of the law is that courts are more willing to find that hospitals have increased obligations to supervise staff, hire competent personnel, and to create appropriate policies and procedures

156. Clark, 628 N.E.2d at 53 .

157. Martin C. McWilliams, Jr. \& Hamilton E. Russell, III, Hospital Liability for Torts of Independent Contractor Physicians, 47 S.C. L. REV. 431, 473 (1996).

158. Id.

159. With the recent emphasis on medical errors eradication and patient safety throughout the country, a hospital's role in checking or evaluating the informed consent process undertaken by physicians, who are agents of the hospital, will improve patient care and ensure physicians are properly informing patients. For information on the 2003 National Patient Safety Goals, see http://www.jcaho.org/accredited+organizations/patient+safety/npsg.htm (last visited Oct. 24, 2003). See also Doing What Counts for Patient Safety: Federal Actions to Reduce Medical Errors and Their Impact, at www.healthsafetyinfo.com/pdf/errors.pdf (last visited Nov. 21, 2003).

160. FURROW ET AL., supra note 33, at 339 . Historically, as medicine has advanced, physicians have become more and more dependent on hospitals for the diagnostic and therapeutic services that only they can provide. See Dallon, supra note 127, at 601 . 
regarding patient care. ${ }^{161}$ Third, courts are becoming less deferential to physicians because delivery of health care is viewed more as a team concept and hospitals are vital support in the care of a patient. ${ }^{162}$ Lastly, the hospital and its administration have the responsibility to ensure completeness of records for reimbursement and monitoring of health care. Written consent forms aid in the completeness of records even though some may contend the forms only provide "bureaucratic formality." 163 It has been asserted that the hospital is in the "best position to monitor conduct within its walls, to enforce adherence to policies, and to provide a source of compensation to injured patients."164

If hospitals eventually become susceptible for the failed informed consent of the physicians whose work is conducted virtually exclusively within its walls, both healthcare costs and patient care could be affected. If hospitals do not plan accordingly to insulate themselves from liability, the costs of litigation would most likely be passed on to the patients. ${ }^{165}$ Accordingly, Justice Flaherty, in Thompson, was concerned about costs and proclaimed the corporate liability doctrine (establishing a direct duty owed by the hospital to the patient) was a "deep pocket theory of liability, placing financial burdens upon hospitals for the actions of persons who are not even their own employees." 166

It has been noted, however, that informed decision making actually could improve health care cost containment because a more informed patient may choose the less expensive procedure. ${ }^{167}$ Patients today realize the financial incentives and pressures involved in providing health care. In addition, patients have many more resources today to educate themselves about different procedures and alternatives.

\section{CONCLUSION}

Today's hospital is a health care provider and cannot hold itself out as a multi-service facility providing any and all care a patient may need without eventually assuming all of the responsibilities and risks that come along with offering this type of service. The dynamic physician-patient relationship is

161. FURROW ET AL., supra note 33, at 339.

162. Id.

163. Id.

164. Id. at 381 .

165. With the rising healthcare costs at issue, President George W. Bush called for medical liability reform in January of 2003. The President reasoned that there are too many frivolous lawsuits brought against hospitals and physicians. The President proposed malpractice "caps" on non-economic and punitive damages, in addition to the implementation of joint and several liability on the medical liability system. President Calls for Medical Liability Reform, at http:// www.whitehouse.gov/news/releases/2003/01/20030116-1.html (last visited Oct. 24, 2003).

166. Thompson v. Nason Hosp., 591 A.2d 703, 709 (Pa. 1991).

167. Joan H. Krause, Reconceptualizing Informed Consent in an Era of Health Care Cost Containment, 85 IOWA L. REV. 261, 363 (1999). 
not as individualized as it has been in the past, and if theories of non-delegable duty, agency, corporate liability or voluntary assumption of duty are extended, the hospital may find itself in a position of accountability for the informed consent procedure.

In order to decrease potential liability and increase quality of care, hospitals must proactively collaborate with physicians, who work primarily within such facilities, to develop a better system of obtaining informed consent. Additionally, hospitals should ensure that physicians are current on education and new information affecting their specialty fields and require hospital personnel to understand their role in the informed consent procedure. Thus, through the efforts of the hospital, communication will improve between everyone involved, the risk of liability will decrease, and ultimately patient care will be enhanced. 